\title{
A selective nanocatalyst for an efficient Ugi reaction: Magnetically recoverable $\mathrm{Cu}(\mathrm{acac})_{2} / \mathrm{NH}_{2}-\mathrm{T} / \mathrm{SiO}_{2} @ \mathrm{Fe}_{3} \mathrm{O}_{4}$ nanoparticles
}

\author{
MONIREH GHAVAMI, MARYAM KOOHI and MOHAMMAD ZAMAN KASSAEE* \\ Department of Chemistry, Tarbiat Modares University, P.O. Box 14155-4838, Tehran, Iran \\ e-mail: kassaeem@modares.ac.ir
}

MS received 13 April 2013; revised 13 August 2013; accepted 13 August 2013

\begin{abstract}
A novel, magnetically recoverable nanocatalyst is fabricated through simple immobilization of copper(II) acetylacetonate on the surface of amine-terminated silica-coated $\mathrm{Fe}_{3} \mathrm{O}_{4}$ nanoparticles: $\mathrm{Cu}(\mathrm{acac})_{2} / \mathrm{NH}_{2}-\mathrm{T} / \mathrm{SiO}_{2} @ \mathrm{Fe}_{3} \mathrm{O}_{4} \mathrm{NPs}$. Unambiguous bonding of $\mathrm{Cu}$ to the terminal amine is indicated by $\mathrm{X}-$ ray photoelectron spectroscopy (XPS). Further characterizations are carried out by different techniques. Selectivity of this catalyst is demonstrated through one-pot synthesis of fourteen $\alpha$-aminoacyl amides using Ugi four-component reaction of cyclohexyl isocyanide, acetic acid, amines and various aldehydes. Interestingly, all aromatic aldehydes react with short reaction times and high yields, but heteroaromatic aldehydes do not yield any product. Catalyst efficiency remains unaltered through three consecutive experiments.
\end{abstract}

Keywords. Nano; $\mathrm{Fe}_{3} \mathrm{O}_{4}$; copper(II) acetylacetonate; Ugi reaction; nanocatalyst.

\section{Introduction}

Transition-metal-catalysed reactions have contributed greatly to the straightforward and facile construction of carbon-carbon or carbon-heteroatom bonds. ${ }^{1}$ Significant progress in this area has been achieved with a variety of homogeneous copper catalysts. ${ }^{2}$ Copper complexes are extensively used as efficient catalysts in multicomponent reactions. ${ }^{3}$ Nevertheless, homogeneous catalysis suffers from the problematic separation of catalyst from the product for reuse. ${ }^{4}$ This problem is of particular environmental and economic concerns in large-scale syntheses. Heterogeneity of the existing homogeneous copper catalysts could be an attractive solution to this problem. ${ }^{5,6}$ In fact, the last decade has witnessed a growing interest in the heterogenization of homogeneous metal complexes using several types of supports and many immobilization strategies. ${ }^{7-10}$ Initially, the complexes are just ion-exchanged or adsorbed on the porous supports and could be susceptible to leaching. ${ }^{11,12}$ More recently, various grafting and tethering procedures have been developed for covalent attachment of transition-metal complexes to organic polymers, silica, zeolites as well as other micro- and mesoporous inorganic materials. ${ }^{7-10}$

Copper(II) acetylacetonate has already been immobilized in a polymer, ${ }^{13}$ hexagonal mesoporous silica

\footnotetext{
*For correspondence
}

(HMS), ${ }^{5}$ and activated carbon. ${ }^{14,15}$ These materials have acted as recoverable and reusable heterogeneous catalysts for the aziridination of olefins. In the first case, the copper(II) complex is microencapsulated in polystyrene, and in the second, a hexagonal mesoporous silica (HMS) is chosen to anchor copper(II) acetylacetonate. In the latter, it is anchored onto an amine-functionalized activated carbon. ${ }^{14}$ All three heterogeneous catalysts present similar catalytic parameters as those obtained in homogeneous-phase reaction using $\left[\mathrm{Cu}(\mathrm{acac})_{2}\right]$. Under similar experimental conditions, no significant metal complex leaching is observed after the catalytic reactions. ${ }^{13,15}$ However, in the case where activated carbon is used as support, inherent diffusion limitations are observed due to the porous structure of the support. Thus, a decrease in the initial activity (TOF) and an increase in the reaction time are observed. ${ }^{15}$ Furthermore, the spectroscopic characterization of new carbon-based heterogeneous catalysts proved to be difficult and impossible, respectively, due to the highly absorbing carbon matrix, which limits the gathering of information about the copper(II) complex forms on the surface of the amine-functionalized activated carbon.

Magnetite $\mathrm{Fe}_{3} \mathrm{O}_{4}$ nanoparticles $\left(\mathrm{Fe}_{3} \mathrm{O}_{4} \mathrm{NPs}\right)$ have recently emerged as promising supports for immobilization because $\mathrm{Fe}_{3} \mathrm{O}_{4}$-supported catalysts can be separated from the reaction medium by an external magnet. ${ }^{16-23}$ This circumvents time-consuming and laborious separation steps, and allows for practical continuous catalysis. In particular, $\mathrm{Fe}_{3} \mathrm{O}_{4} \mathrm{NPs}$ coated with a thin-layer of silica 

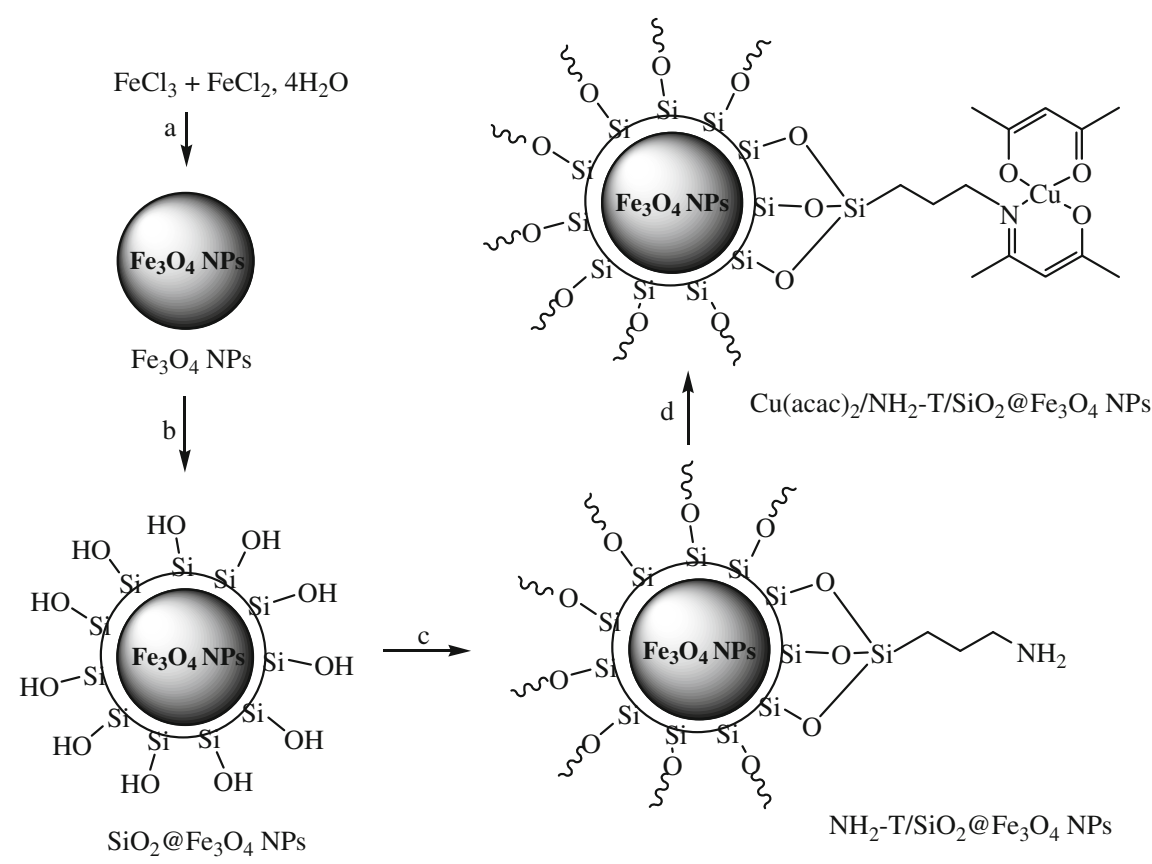

Scheme 1. Stepwise synthesis of our magnetic nanocatalyst $\left(\mathrm{Cu}(\mathrm{acac})_{2} / \mathrm{NH}_{2}-\right.$ $\mathrm{T} / \mathrm{SiO}_{2} @ \mathrm{Fe}_{3} \mathrm{O}_{4} \mathrm{NPs}$ ): (a) aqueous ammonia (25\%), rt; (b) tetraethyl orthosilicate, EtOH, aqueous ammonia $(10 \%)$, rt, $10 \mathrm{~h}$ then $40^{\circ} \mathrm{C}, 12 \mathrm{~h}$; (c) (3aminopropyl)triethoxysilane, toluene, $105^{\circ} \mathrm{C}, 24 \mathrm{~h} ;$ (d) $\mathrm{Cu}(\mathrm{acac})_{2}$, toluene, $105^{\circ} \mathrm{C}, 5 \mathrm{~h}$.

have beneficial properties such as invariant catalytic activity and stability. ${ }^{24}$

On the other hand, Ugi four-component reaction (U$4 \mathrm{CR}$ ) is arguably one of the most important isocyanidebased multicomponent reactions, IMCRs. ${ }^{25-27}$ It is a valuable method for generating $\alpha$-aminoacyl amide derivatives in a very straightforward manner by condensing an aldehyde, amine, carboxylic acid, and isocyanide in one-pot reaction. ${ }^{25}$ Lewis acids are not required for majority of the reported IMCRs, but they have been applied as catalyst for U-4CR. ${ }^{28-37}$ Yet, conventional U-4CR gives good yields, but shows no selectivity, taking 24-72 h to complete at room temperature. ${ }^{26}$ Due to the great diversity of products which can be obtained by the post-modifications of the U$4 \mathrm{CR}$ with other reactions, selectivity and the time of this reaction remain as important parameters in

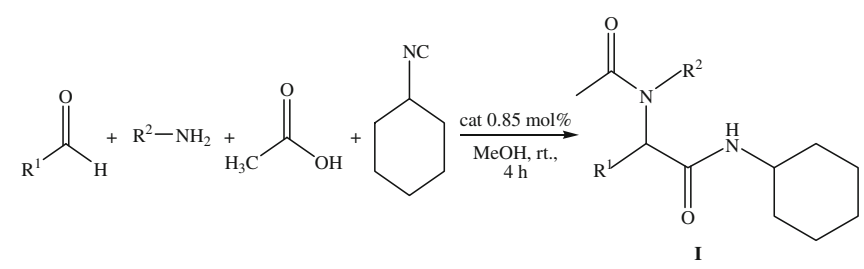

Scheme 2. One-pot catalytic synthesis of $\alpha$-aminoacyl amides (I) through Ugi reaction via $\mathrm{Cu}(\mathrm{acac})_{2} / \mathrm{NH}_{2}$ $\mathrm{T} / \mathrm{SiO}_{2} @ \mathrm{Fe}_{3} \mathrm{O}_{4} \mathrm{NPs}$. combinational strategy. ${ }^{27}$ Thus, we present herein the possibility of a new U-4CR design, using a novel catalyst, for decreasing reaction time and increasing selectivity. In this context, we are reporting a facile route for synthesis of our magnetic nanocatalyst, $\mathrm{Cu}(\mathrm{acac})_{2} / \mathrm{NH}_{2}-\mathrm{T} / \mathrm{SiO}_{2} @ \mathrm{Fe}_{3} \mathrm{O}_{4} \mathrm{NPs}$ (scheme 1); followed by examination of its feasibility as a heterogeneous catalyst in U-4CR (scheme 2).

Catalytic activity of the heterogeneous copper complex is compared with the parent-free complex $\left[\mathrm{Cu}(\mathrm{acac})_{2}\right]$. In this context, the former heterogeneous catalyst showed similar catalytic efficiency, turnover numbers (TON) and turnover frequency (TOF), compared to the free $\left[\mathrm{Cu}(\mathrm{acac})_{2}\right]$ in the homogeneous phase, under similar experimental conditions.

\section{Experimental}

\subsection{Chemicals and instruments}

Reagents and solvents used in this study are obtained from Fluka or Merck and used without any further purification. Nanostructures are characterized using a Holland Philips Xpert X-ray powder diffraction (XRD) diffractometer $(\mathrm{Cu} \mathrm{K} \alpha$, radiation, $\lambda=1.54 \AA)$, at a scanning speed of $2^{\circ} / \mathrm{min}$ from $10^{\circ}$ to $80^{\circ}(2 \theta)$. Particle size and morphology are investigated by PHILIPS (EM208S, The Netherlands) transmission electron 
microscopy (TEM) at $100 \mathrm{kV}$ of acceleration voltage and scanning electron microscopy (SEM) of a Holland Philips XL30 microscope with an accelerating voltage of $25 \mathrm{kV}$. Fourier transform infrared (FTIR) measurements are performed using $\mathrm{KBr}$ disc on a Thermo IR-100 spectrometer (Nicolet). ${ }^{1} \mathrm{H}$ - and ${ }^{13} \mathrm{C}$-spectra are measured at 500.1 and $125.7 \mathrm{MHz}$, respectively, on a Bruker DRX 500-Avance NMR instrument with $\mathrm{CDCl}_{3}$ or DMSO- $d_{6}$ as the solvent. Melting points are measured on an Electrothermal 9100 apparatus. X-ray photoelectron spectroscopy (XPS) experiment is carried out on a TWIN ANODE XR3E2 X-RAY source system with $\mathrm{Al} K \alpha$ radiation $(h v=1486.6 \mathrm{eV})$. Thermogravimetric analysis (TGA) curves are recorded using a PL-TGA device, manufactured by Polymer Laboratories. Magnetic properties of $\mathrm{Fe}_{3} \mathrm{O}_{4} \mathrm{NPs}$ and $\mathrm{Cu}(\mathrm{acac})_{2} /$ $\mathrm{NH}_{2}-\mathrm{T} / \mathrm{SiO}_{2} @ \mathrm{Fe}_{3} \mathrm{O}_{4} \mathrm{NPs}$ are measured as a function of the applied magnetic field $H$ using a LDJ 9600 vibrating sample magnetometer (VSM) (AGFM-Meghnatis Daghigh Kavir Co.) with a maximum applied magnetic field of $10 \mathrm{kOe}$. Hysteresis of the magnetization is obtained by varying $H$ between +10000 and $-10000 \mathrm{Oe}$ at $300 \mathrm{~K}$.

\subsection{Synthesis of $\mathrm{Fe}_{3} \mathrm{O}_{4} \mathrm{NPs}$}

In the formation of $\mathrm{Fe}_{3} \mathrm{O}_{4} \mathrm{NPs}, 2 \mathrm{~g} \mathrm{FeCl}_{3}$ and $1.2 \mathrm{~g}$ of $\mathrm{FeCl}_{2} \cdot 4 \mathrm{H}_{2} \mathrm{O}$, with molar ratio of $\left(\mathrm{Fe}^{3+}: \mathrm{Fe}^{2+}=2: 1\right)$ are dissolved in aqueous hydrochloride acid $(2 \mathrm{M}$, $25 \mathrm{ml}$ ), then sonicated until the salts dissolve completely. Aqueous ammonia $(25 \%, 20 \mathrm{ml})$ is added slowly over $20 \mathrm{~min}$ to the solution with vigorous stirring under argon atmosphere at room temperature followed by stirring for about $30 \mathrm{~min}$ with mechanical stirrer. The $\mathrm{Fe}_{3} \mathrm{O}_{4} \mathrm{NPs}$ are separated by external magnet and washed thrice with deionized water and ethanol. The final product could either be obtained after drying under vacuum, or stored as a suspension in ethanol in refrigerator, for future use.

\subsection{Synthesis of silica-coated $\mathrm{Fe}_{3} \mathrm{O}_{4}$ nanoparticles $\left(\mathrm{SiO}_{2} @ \mathrm{Fe}_{3} \mathrm{O}_{4} \mathrm{NPs}\right)$}

$\mathrm{SiO}_{2} @ \mathrm{Fe}_{3} \mathrm{O}_{4} \mathrm{NPs}$ is produced by hydrolysis of tetraethylorthosilicate (TEOS) on the surfaces of the $\mathrm{Fe}_{3} \mathrm{O}_{4} \mathrm{NPs}$. The precipitate $\mathrm{Fe}_{3} \mathrm{O}_{4}$ is ultrasonically redispersed in a solution containing $35 \mathrm{ml}$ ethanol and $6 \mathrm{ml}$ water. The $\mathrm{pH}$ value is adjusted to 9 with an ammonia solution, then $1.5 \mathrm{ml} \mathrm{3-aminopropyltriethoxysilane}$ (APTES) is added under vigorous stirring for $10 \mathrm{~h}$. To further hydrolyse, the ferro-fluid is heated at $50^{\circ} \mathrm{C}$ for
$12 \mathrm{~h}$. Consequently, the iron oxide nanoparticles with a thin-layer of silica $\left(\mathrm{SiO}_{2} @ \mathrm{Fe}_{3} \mathrm{O}_{4} \mathrm{NPs}\right)$ are separated by an external magnet and washed thrice with ethanol and dried under vacuum.

\subsection{Functionalization of the $\mathrm{SiO}_{2} @ \mathrm{Fe}_{3} \mathrm{O}_{4} \mathrm{NPs}$ with APTES $\left(\mathrm{NH}_{2}-\mathrm{T} / \mathrm{SiO}_{2} @ \mathrm{Fe}_{3} \mathrm{O}_{4} \mathrm{NPS}\right)$}

$\mathrm{SiO}_{2} @ \mathrm{Fe}_{3} \mathrm{O}_{4} \mathrm{NPs}$ is ultrasonically dispersed in a solution containing $20 \mathrm{ml}$ toluene. 3-aminopropyltriethoxysilane (APTES) $(1 \mathrm{ml})$ is added drop-wise into the bottle under magnetic stirring. After hydrolysing for $24 \mathrm{~h}$ at room temperature, the particles are collected by an external magnet and washed with toluene several times with the help of an external magnet, then dried under vacuum. Thus, silica-coated $\mathrm{Fe}_{3} \mathrm{O}_{4} \mathrm{NPs}$, functionalized by $-\mathrm{NH}_{2}$ groups are obtained: $\mathrm{NH}_{2}-$ $\mathrm{T} / \mathrm{SiO}_{2} @ \mathrm{Fe}_{3} \mathrm{O}_{4} \mathrm{NPs}$.

\subsection{Synthesis of $\mathrm{Cu}(\mathrm{acac})_{2} / \mathrm{NH}_{2}-\mathrm{T} / \mathrm{SiO}_{2} @ \mathrm{Fe}_{3} \mathrm{O}_{4} \mathrm{NPs}$}

Synthesized $\mathrm{NH}_{2}-\mathrm{T} / \mathrm{SiO}_{2} @ \mathrm{Fe}_{3} \mathrm{O}_{4} \mathrm{NPs}(1.0 \mathrm{~g})$ is added to $50 \mathrm{ml}$ of a solution of $\left[\mathrm{Cu}(\mathrm{acac})_{2}\right](4 \mathrm{mmol})$ in toluene, the mixture is refluxed for $5 \mathrm{~h}$. A progressive disappearance of solution colour is observed. The resulting material $\left(\mathrm{Cu}(\mathrm{acac})_{2} / \mathrm{NH}_{2}-\mathrm{T} / \mathrm{SiO}_{2} @ \mathrm{Fe}_{3} \mathrm{O}_{4} \mathrm{NPs}\right)$ is extensively washed with toluene and then dried at $50^{\circ} \mathrm{C}$ for $13 \mathrm{~h}$.

\subsection{General procedure for Ugi four-component reaction $(U-4 C R)$}

Butylamine ( $1 \mathrm{mmol})$ is added to a solution of aldehyde ( $1 \mathrm{mmol})$ and $\mathrm{Cu}(\mathrm{acac})_{2} / \mathrm{NH}_{2}-\mathrm{T} / \mathrm{SiO}_{2} @ \mathrm{Fe}_{3} \mathrm{O}_{4} \mathrm{NPs}$ $(0.85 \mathrm{~mol} \%)$ in methanol $(5 \mathrm{ml})$, and the reaction mixture is stirred at room temperature for $1 \mathrm{~h}$. Then, acetic acid ( $1 \mathrm{mmol})$ is added and stirring is continued for $15 \mathrm{~min}$. Cyclohexyl isocyanide $(1 \mathrm{mmol})$ is added and stirring is continued for $4 \mathrm{~h}$ until the reaction is completed (indication by thin layer chromatography (TLC)). The catalyst is recovered after placing a magnet on the reactor wall and decanting the reaction mixture which contains the product in either insoluble or soluble form. Filtration and/or column chromatography of the reaction mixture on silica (ethyl acetate/hexane) affords the pure product. The recovered catalyst is washed twice with methanol and dried at $50^{\circ} \mathrm{C}$, then reused in the next run. Loss of the catalyst, in the process of separation, appears minimal and is negligible. 


\section{Results and discussion}

In this section, complete characterization of our nanocatalyst $\left(\mathrm{Cu}(\mathrm{acac})_{2} / \mathrm{NH}_{2}-\mathrm{T} / \mathrm{SiO}_{2} @ \mathrm{Fe}_{3} \mathrm{O}_{4} \mathrm{NPs}\right)$ is followed by its synthetic application. In the following subsections, morphology and particle size of constituting $\mathrm{Fe}_{3} \mathrm{O}_{4} \mathrm{NPs}$ are characterized by SEM and TEM. Surface area of the catalyst is estimated by Brunauer-Emmet-Teller (BET). Evidence for the effective irreversible attachment of $\left[\mathrm{Cu}(\mathrm{acac})_{2}\right]$ on the surface of $\mathrm{NH}_{2}-\mathrm{T} / \mathrm{SiO}_{2} @ \mathrm{Fe}_{3} \mathrm{O}_{4} \mathrm{NPs}$ is indicated by colour change and confirmed by XRD, XPS, Inductively coupled plasma (ICP), FTIR, and TGA analyses. Magnetic properties of $\mathrm{Fe}_{3} \mathrm{O}_{4} \mathrm{NPs}$ and $\mathrm{Cu}(\mathrm{acac})_{2} / \mathrm{NH}_{2}-$ $\mathrm{T} / \mathrm{SiO}_{2} @ \mathrm{Fe}_{3} \mathrm{O}_{4} \mathrm{NPs}$ are determined by VSM. Subsequently, the applicability, selectivity, efficiency, and reusability of the catalyst are discussed in light of onepot synthesis of $\alpha$-aminoacyl amides (I) using Ugi fourcomponent reaction (U-4CR) of cyclohexyl isocyanide, acetic acid, various amines and aldehydes.

\subsection{Morphology, particle size and surface area (via SEM, TEM and BET)}

The $\mathrm{Fe}_{3} \mathrm{O}_{4}$ magnetic nanoparticles $\left(\mathrm{Fe}_{3} \mathrm{O}_{4} \mathrm{NPs}\right)$ come into view with an approximate spherical shape in
SEM and TEM (figure 1). In accord with TEM, which provides rather more accurate information on the particle size than SEM, average diameter of the core is around $9.8 \mathrm{~nm}$ (figure $1 \mathrm{~b}$ and $\mathrm{c}$ ). Using BET method, surface area $\left(S_{\mathrm{BET}}\right)$ and the total pore volume $\left(V_{\mathrm{p}}\right)$ appear fairly ideal for active $\mathrm{Cu}(\text { acac })_{2} / \mathrm{NH}_{2}-\mathrm{T} / \mathrm{SiO}_{2}$ $@ \mathrm{Fe}_{3} \mathrm{O}_{4} \mathrm{NPs}$, with $29 \mathrm{~m}^{2} \mathrm{~g}^{-1}$ and $0.12 \mathrm{~cm}^{3} \mathrm{~g}^{-1}$, respectively. Owing to the remarkable increase in particle size during functionalization of $\mathrm{Fe}_{3} \mathrm{O}_{4} \mathrm{NPs}$, specific surface area is greatly reduced from $\mathrm{Fe}_{3} \mathrm{O}_{4} \mathrm{NPs}$ $\left(221.5 \mathrm{~m}^{2} \mathrm{~g}^{-1}\right)$ to $\mathrm{SiO}_{2} @ \mathrm{Fe}_{3} \mathrm{O}_{4} \mathrm{NPs}\left(58.1 \mathrm{~m}^{2} \mathrm{~g}^{-1}\right), \mathrm{NH}_{2}-$ $\mathrm{T} / \mathrm{SiO}_{2} @ \mathrm{Fe}_{3} \mathrm{O}_{4} \mathrm{NPs}\left(42 \mathrm{~m}^{2} \mathrm{~g}^{-1}\right)$, and $\mathrm{Cu}(\mathrm{acac})_{2} / \mathrm{NH}_{2}-$ $\mathrm{T} / \mathrm{SiO}_{2} @ \mathrm{Fe}_{3} \mathrm{O}_{4} \mathrm{NPs}\left(29 \mathrm{~m}^{2} \mathrm{~g}^{-1}\right)$. These results confirm $\mathrm{Fe}_{3} \mathrm{O}_{4} \mathrm{NPs}$ functionalizations.

\subsection{Structural analysis of the catalyst and its components (via XRD)}

The XRD patterns are compared and contrasted for $\mathrm{Fe}_{3} \mathrm{O}_{4} \mathrm{NPs}, \mathrm{SiO}_{2} @ \mathrm{Fe}_{3} \mathrm{O}_{4} \mathrm{NPs}, \mathrm{NH}_{2}-\mathrm{T} / \mathrm{SiO}_{2} @ \mathrm{Fe}_{3} \mathrm{O}_{4} \mathrm{NPs}$, and $\mathrm{Cu}(\mathrm{acac})_{2} / \mathrm{NH}_{2}-\mathrm{T} / \mathrm{SiO}_{2} @ \mathrm{Fe}_{3} \mathrm{O}_{4} \mathrm{NPs}$ (figure 2). The position and relative intensities of all peaks coincide with standard XRD pattern of $\mathrm{Fe}_{3} \mathrm{O}_{4}$ (JCPDS card No. 19-0629), indicating retention of the crystalline structure during functionalization of $\mathrm{Fe}_{3} \mathrm{O}_{4} \mathrm{NPs}$. Average $\mathrm{Fe}_{3} \mathrm{O}_{4} \mathrm{NPs}$ core diameter is calculated to be $10 \mathrm{~nm}$ from

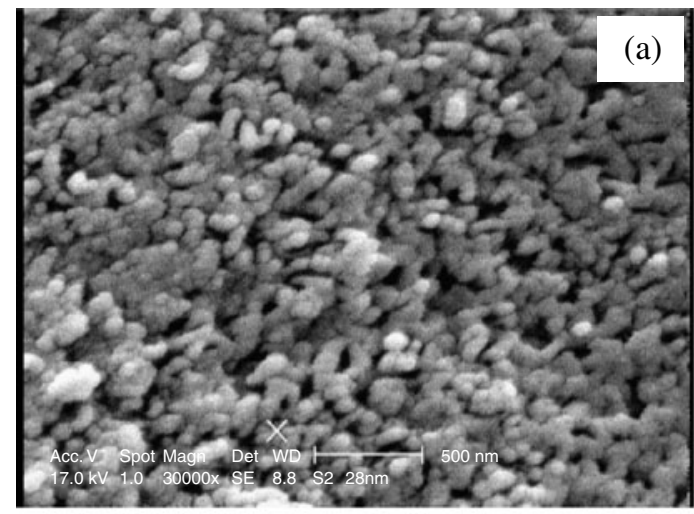

(c)
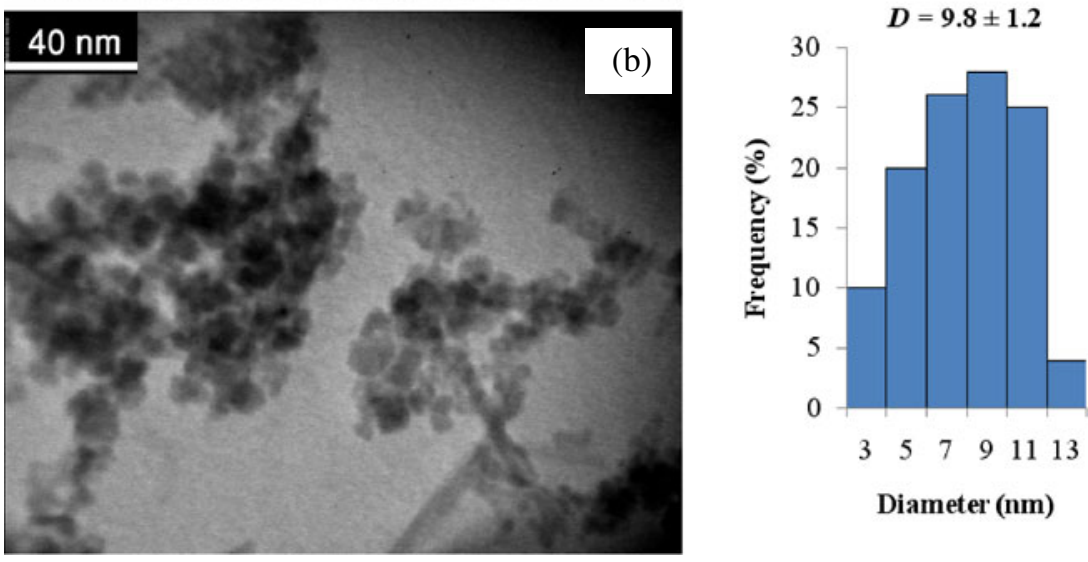

Figure 1. (a) SEM, (b) TEM images, and (c) Particle size histogram of our $\mathrm{F}_{3} \mathrm{O}_{4} \mathrm{NPs}_{\text {. }}$ 


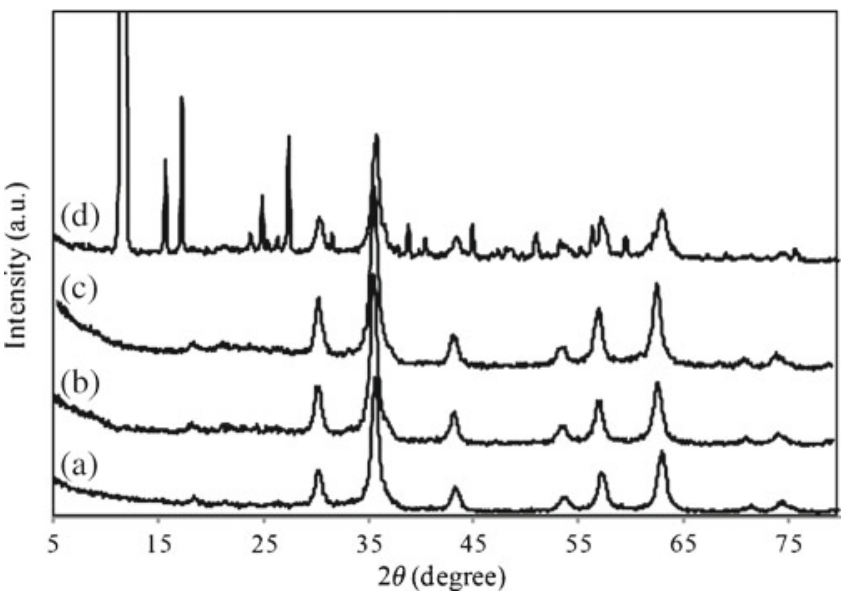

Figure 2. XRD patterns of (a) $\mathrm{Fe}_{3} \mathrm{O}_{4} \mathrm{NPs}$, (b) $\mathrm{SiO}_{2} @ \mathrm{Fe}_{3}$ $\mathrm{O}_{4} \mathrm{NPs}$, (c) $\mathrm{NH}_{2}-\mathrm{T} / \mathrm{SiO}_{2} @ \mathrm{Fe}_{3} \mathrm{O}_{4} \mathrm{NPs}$ and (d) $\mathrm{Cu}(\mathrm{acac})_{2} /$ $\mathrm{NH}_{2}-\mathrm{T} / \mathrm{SiO}_{2} @ \mathrm{Fe}_{3} \mathrm{O}_{4} \mathrm{NPs}$.

the XRD results by Scherrer's equation, $\mathrm{D}=k \lambda / \beta \cos \theta$, where $k$ is a constant (generally considered as 0.94), $\lambda$ is the wavelength of $\mathrm{Cu} \mathrm{Ka}(1.54 \AA), \beta$ is the corrected diffraction line full-width at half-maximum (FWHM), and $\theta$ is Bragg's angle, ${ }^{38}$ which is in good accordance with its TEM. A weak broad band at $2 \theta=18-27^{\circ}$ could be assigned to the amorphous silane shell formed around the magnetic cores (figure $2 b$ and $c$ ). ${ }^{39}$ The XRD pattern of $\mathrm{Cu}(\mathrm{acac})_{2} / \mathrm{NH}_{2}-\mathrm{T} / \mathrm{SiO}_{2} @ \mathrm{Fe}_{3} \mathrm{O}_{4} \mathrm{NPs}$ indicates an effective anchorage of $\mathrm{Cu}(\mathrm{acac})_{2}$ onto the surface of $\mathrm{NH}_{2}-\mathrm{T} / \mathrm{SiO}_{2} @ \mathrm{Fe}_{3} \mathrm{O}_{4} \mathrm{NPs}$, with lines at $2 \theta=$ $11.70,15.55,17.12,24.73$ and 27.27 (figure $2 \mathrm{~d}$ ). ${ }^{40}$

\subsection{Structural characterization of the catalyst (via $X P S$ and $I C P$ )}

The XPS binding energy of $\mathrm{C} 1 \mathrm{~s}, \mathrm{O} 1 \mathrm{~s}, \mathrm{Si} 2 p, \mathrm{~N} 1 \mathrm{~s}$ and $\mathrm{Cu} 2 \mathrm{p}$, along with the corresponding atomic \% data, confirm the structure of our catalyst, $\mathrm{Cu}(\mathrm{acac})_{2} / \mathrm{NH}_{2}$ $\mathrm{T} / \mathrm{SiO}_{2} @ \mathrm{Fe}_{3} \mathrm{O}_{4} \mathrm{NPs}$ (table 1, figure 3).

For carbon spectra, the main change is the appearance of a new shoulder around $288.0 \mathrm{eV}$ in $\mathrm{Cu}(\mathrm{acac})_{2} /$ $\mathrm{NH}_{2}-\mathrm{T} / \mathrm{SiO}_{2} @ \mathrm{Fe}_{3} \mathrm{O}_{4} \mathrm{NPs}$ (figure 3, C 1s, $\mathrm{S}_{4}$ ), which could be attributed to the $\mathrm{C}=\mathrm{N}, \mathrm{C}-\mathrm{N}$, and $\mathrm{C}=\mathrm{O}$ groups, indicating the anchoring of $\mathrm{Cu}(\mathrm{acac})_{2}$ in $\mathrm{NH}_{2}-$ $\mathrm{T} / \mathrm{SiO}_{2} @ \mathrm{Fe}_{3} \mathrm{O}_{4} \mathrm{NPs}$.

Oxygen anions in the lattice of $\mathrm{Fe}_{3} \mathrm{O}_{4} \mathrm{NPs}$ give the $\mathrm{O}$ $1 \mathrm{~s}$ peak at $528 \mathrm{eV}$ (figure $3, \mathrm{C} 1 \mathrm{~s}, \mathrm{~S}_{1}$ ). ${ }^{41}$ Oxygen anions in $\mathrm{SiO}_{2} @ \mathrm{Fe}_{3} \mathrm{O}_{4} \mathrm{NPs}$ and $\mathrm{NH}_{2}-\mathrm{T} / \mathrm{SiO}_{2} @ \mathrm{Fe}_{3} \mathrm{O}_{4} \mathrm{NPs}$ samples give a shoulder at $528 \mathrm{eV}$ (figure 3, O1s, $\mathrm{S}_{2}$ and $\mathrm{S}_{3}$ ), while the region near $530 \mathrm{eV}$ (figure $3, \mathrm{O} 1 \mathrm{~s}, \mathrm{~S}_{2}, \mathrm{~S}_{3}$, and $\mathrm{S}_{4}$ ) could be attributed to either $\mathrm{C}-\mathrm{O}$ and $/$ or $\mathrm{C}=\mathrm{O}$ and $\mathrm{Si}-\mathrm{O}$ surface species. ${ }^{42}$ As XPS can only measure the elements on the most outer surface, there is no signal at $528 \mathrm{eV}$ in $\left(\mathrm{Cu}(\mathrm{acac})_{2} / \mathrm{NH}_{2}-\mathrm{T} / \mathrm{SiO}_{2} @ \mathrm{Fe}_{3} \mathrm{O}_{4} \mathrm{NPs}\right)$ (figure $3, \mathrm{O} 1 \mathrm{~s}, \mathrm{~S}_{4}$ ). This is in agreement with the BET results.

The Si $2 p$ spectra consist of major peaks centred at approximately $103 \mathrm{eV}$ (Si-O) (figure 3, Si 2p $\mathrm{S}_{2}$ ). Both $\mathrm{NH}_{2}-\mathrm{T} / \mathrm{SiO}_{2} @ \mathrm{Fe}_{3} \mathrm{O}_{4} \mathrm{NPs}$ and $\mathrm{Cu}(\mathrm{acac})_{2} / \mathrm{NH}_{2}-$ $\mathrm{T} / \mathrm{SiO}_{2} @ \mathrm{Fe}_{3} \mathrm{O}_{4} \mathrm{NPs}$ give similar spectra. XPS results of the two samples show a new weak shoulder around $101.1 \mathrm{eV},{ }^{43}$ which could be attributed to the $\mathrm{C}-\mathrm{Si}-\mathrm{O}_{3}$, indicating the grafting of the APTES to $\mathrm{SiO}_{2} @ \mathrm{Fe}_{3} \mathrm{O}_{4} \mathrm{NPs}$ (figure 3, Si $2 \mathrm{p} \mathrm{S}_{3}$ and $\mathrm{S}_{4}$ ).

Specifically, deconvolution of C $1 s$ into five components indicates $\mathrm{C}-\mathrm{Si}(\mathrm{A})$, hydrocarbon or hydrocarbon groups $(\mathrm{B}), \mathrm{C}=\mathrm{N}(\mathrm{C}), \mathrm{C}-\mathrm{N}(\mathrm{D})$, and $\mathrm{C}=\mathrm{O}(\mathrm{E})$ at 283.22, 284.71, 285.61, 286.38, and $288.32 \mathrm{eV}$, respectively (figure 4). ${ }^{44}$ The latter binding energy establishes unambiguous formation of $\mathrm{C}=\mathrm{N}$ bond and hence the anchorage of $\mathrm{Cu}(\mathrm{acac})_{2}$ onto the surface of $\mathrm{NH}_{2}-$ $\mathrm{T} / \mathrm{SiO}_{2} @ \mathrm{Fe}_{3} \mathrm{O}_{4} \mathrm{NPs}$. Similarly N 1 s peak is deconvoluted into peaks with maxima at 398.31 and $399.45 \mathrm{eV}$, corresponding to $\mathrm{C}-\mathrm{N}$ and $\mathrm{C}=\mathrm{N}$, respectively (not shown here). The $\mathrm{C}=\mathrm{N}$ binding energies extracted from

Table 1. Structural characterization by XPS data; $\mathrm{Cu}$ amounts (wt.\%) obtained by ICP and XPS analyses.

\begin{tabular}{lcccccc}
\hline Atoms and C-bonds & $\mathrm{BE}(\mathrm{eV})$ & Atomic $(\%)$ & Bond $(\%)$ & $\% \mathrm{Cu}_{\text {XPS }}$ & $\% \mathrm{Cu}$ ICP & $\mathrm{Cu}_{\text {XPS }} / \mathrm{Cu}_{\text {ICP }}$ \\
\hline $\mathrm{C}$ & 285.18 & 49.8 & - & - & - & - \\
$\mathrm{O}$ & 533.44 & 36.5 & - & - & - & - \\
$\mathrm{Si}$ & 101.11 & 9.8 & - & - & - & - \\
$\mathrm{N}$ & 398.2 & 1.5 & - & - & - & - \\
$\mathrm{Cu} \mathrm{2} \mathrm{p}_{3 / 2}$ & 932.47 & 1.2 & - & 10.2 & 5.4 & 1.9 \\
$\mathrm{Cu} \mathrm{2} \mathrm{p}_{1 / 2}$ & 952.92 & 1.2 & - & & - & - \\
$\mathrm{C}-\mathrm{Si}$ & 283.22 & - & 19.3 & - & - & - \\
$\mathrm{C}-\mathrm{C}, \mathrm{C}-\mathrm{H}$ & 284.71 & - & 43.5 & - & - & - \\
$\mathrm{C}=\mathrm{N}$ & 285.61 & - & 9.9 & - & - & - \\
$\mathrm{C}-\mathrm{N}$ & 286.38 & - & 18.4 & - & - & - \\
$\mathrm{C}=\mathrm{O}$ & 288.32 & - & 8.9 & - & - & \\
\hline
\end{tabular}




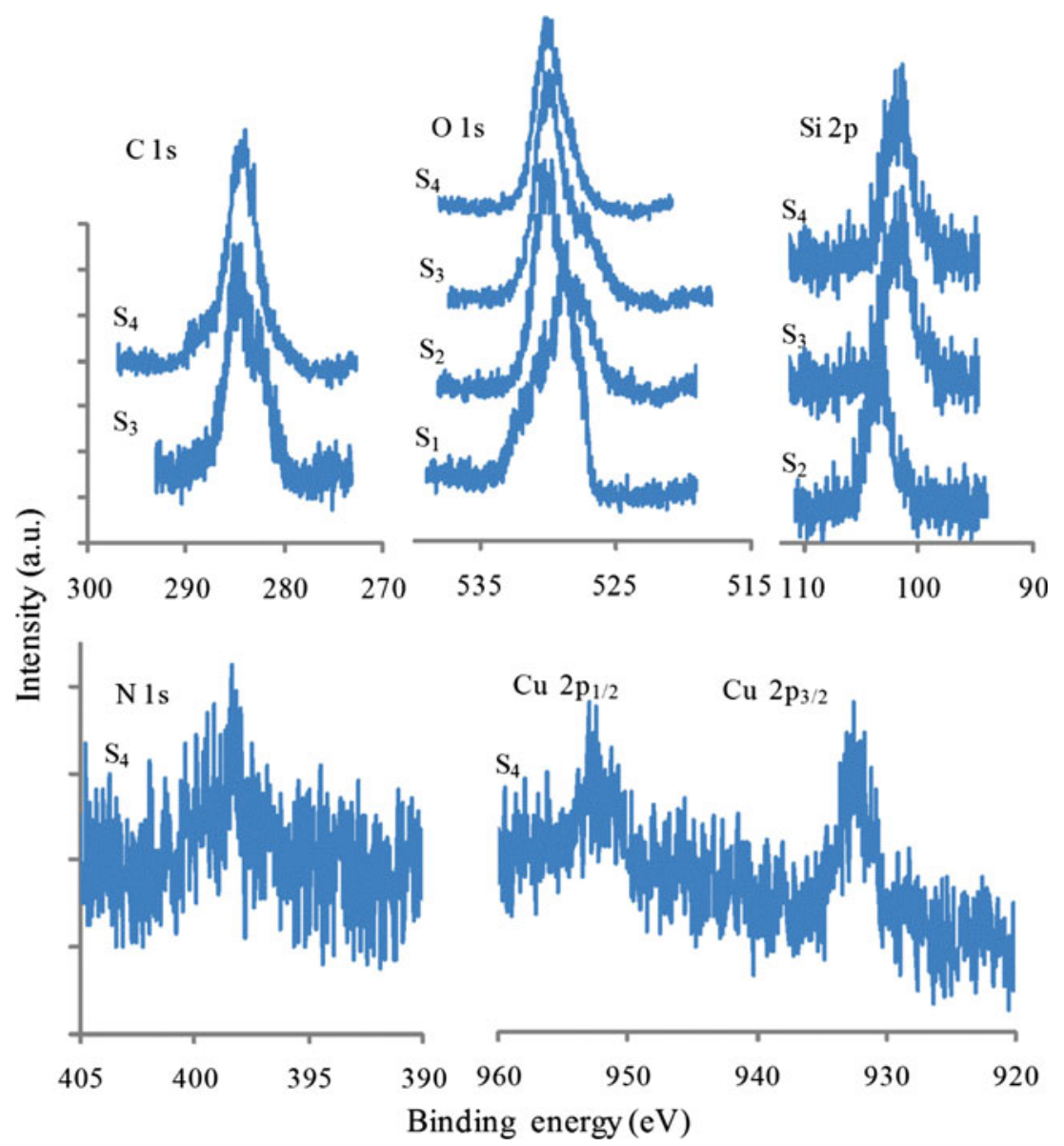

Figure 3. XPS spectra of $\mathrm{Fe}_{3} \mathrm{O}_{4} \mathrm{NPs}\left(\mathrm{S}_{1}\right), \mathrm{SiO}_{2} @ \mathrm{Fe}_{3} \mathrm{O}_{4} \mathrm{NPs}\left(\mathrm{S}_{2}\right), \mathrm{NH}_{2}-$ $\mathrm{T} / \mathrm{SiO}_{2} @ \mathrm{Fe}_{3} \mathrm{O}_{4} \mathrm{NPs}\left(\mathrm{S}_{3}\right)$, and $\mathrm{Cu}(\mathrm{acac})_{2} / \mathrm{NH}_{2}-\mathrm{T} / \mathrm{SiO}_{2} @ \mathrm{Fe}_{3} \mathrm{O}_{4} \mathrm{NPs}\left(\mathrm{S}_{4}\right)$ in the regions of $\mathrm{C} 1 \mathrm{~s}, \mathrm{O} 1 \mathrm{~s}, \mathrm{Si} 2 \mathrm{p}, \mathrm{N}$ 1s, and $\mathrm{Cu} 2 \mathrm{p}$.

$\mathrm{C} 1 s$ and $\mathrm{N} 1 s$ (285.61, and $399.45 \mathrm{eV}$, respectively) belong to the same range as those reported for organic molecules, e.g. pyridine ( 285.5 and $400.6 \mathrm{eV})$, polyacronitrile (286.4 and $399.57 \mathrm{eV}$ ) and hexamethylenetetramine (286.9 and $398.8 \mathrm{eV}) .{ }^{45,46} \mathrm{In}$ the XPS spectrum of $\mathrm{Cu}(\mathrm{acac})_{2}$, a doublet structure appears at 932.47 and $952.92 \mathrm{eV}$, which correspond to $\mathrm{Cu} 2 \mathrm{p}_{3 / 2}$ and $\mathrm{Cu} 2 \mathrm{p}_{1 / 2}$ (figure $3 \mathrm{e}$ ). These peaks are associated with the exis-

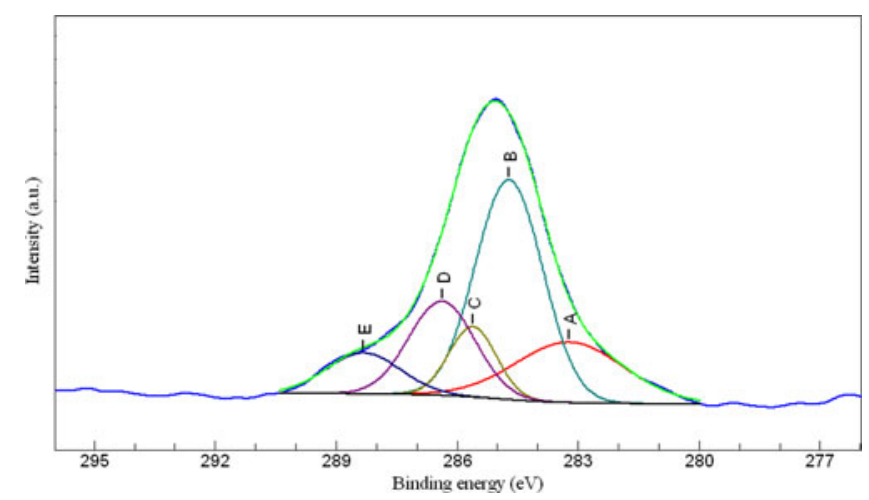

Figure 4. Deconvoluted spectrum of $\mathrm{C} 1 \mathrm{~s}$. tence of unpaired electrons in $\mathrm{Cu}(\mathrm{acac})_{2}$, and are consistent with literature values of 932.6 and $952.2 \mathrm{eV}$, respectively. ${ }^{47,48}$ The ICP and XPS copper content of our catalyst are $5.4 \%$ and $10.2 \%$, respectively (table 2). The ratio of $\mathrm{Cu}_{\mathrm{XPS}} / \mathrm{Cu}_{\mathrm{ICP}}$, with its value of 1.9 , indicates that the $\mathrm{Cu}(\mathrm{acac})_{2}$ is approximately homogeneously distributed on the surface of $\mathrm{NH}_{2}$ $\mathrm{T} / \mathrm{SiO}_{2} @ \mathrm{Fe}_{3} \mathrm{O}_{4} \mathrm{NPs}^{49}$

\subsection{Structural analysis of the catalyst and its components (via FTIR)}

Comparing FTIR spectra of $\mathrm{Fe}_{3} \mathrm{O}_{4} \mathrm{NPs}, \mathrm{SiO}_{2} @ \mathrm{Fe}_{3} \mathrm{O}_{4} \mathrm{NPs}$, $\mathrm{NH}_{2}-\mathrm{T} / \mathrm{SiO}_{2} @ \mathrm{Fe}_{3} \mathrm{O}_{4} \mathrm{NPs}$ and $\mathrm{Cu}(\mathrm{acac})_{2} / \mathrm{NH}_{2}-\mathrm{T} / \mathrm{SiO}_{2} @$ $\mathrm{Fe}_{3} \mathrm{O}_{4} \mathrm{NPs}$ appears instructive (figure 5). The two bands at 600.08 and $437.55 \mathrm{~cm}^{-1}$ are attributed to the stretching vibrations of $\mathrm{Fe}-\mathrm{O}$ in $\mathrm{Fe}_{3} \mathrm{O}_{4}$ nanoparticles (composed of $\mathrm{FeO}$ and $\mathrm{Fe}_{2} \mathrm{O}_{3}$ ). Owing to the size reduction in the nano structure, these vibrations are red-shifted compared to those observed in the bulk $\mathrm{Fe}_{3} \mathrm{O}_{4}$ samples (570 and $375 \mathrm{~cm}^{-1}$, respectively). ${ }^{50,51}$ FTIR spectra 
Table 2. Optimization of the amount of catalyst in Ugi reaction of benzaldehyde, aniline, acetic acid and cyclohexyl isocyanide (scheme 2 ). ${ }^{\mathrm{a}}$

\begin{tabular}{llcrr}
\hline Entry & \multicolumn{1}{c}{ Catalyst $(\mathrm{mol} \%)$} & Yield $(\%)$ & $\mathrm{TON}^{\mathrm{b}}$ & $\mathrm{TOF}^{\mathrm{c}}$ \\
\hline 1 & - & 10 & 12 & 3 \\
2 & $\mathrm{Cu}(\mathrm{acac})_{2} / \mathrm{NH}_{2}-\mathrm{T} / \mathrm{SiO}_{2} @ \mathrm{Fe}_{3} \mathrm{O}_{4} \mathrm{NPs}(0.25)$ & 54 & 63 & 16 \\
3 & $\mathrm{Cu}(\mathrm{acac})_{2} / \mathrm{NH}_{2}-\mathrm{T} / \mathrm{SiO}_{2} @ \mathrm{Fe}_{3} \mathrm{O}_{4} \mathrm{NPs}(0.45)$ & 82 & 96 & 24 \\
4 & $\mathrm{Cu}(\mathrm{acac})_{2} / \mathrm{NH}_{2}-\mathrm{T} / \mathrm{SiO}_{2} @ \mathrm{Fe}_{3} \mathrm{O}_{4} \mathrm{NPs}(0.85)$ & 98 & 115 & 29 \\
5 & $\mathrm{Cu}(\mathrm{acac})_{2} / \mathrm{NH}_{2}-\mathrm{T} / \mathrm{SiO}_{2} @ \mathrm{Fe}_{3} \mathrm{O}_{4} \mathrm{NPs}(1)$ & 98 & 115 & 29 \\
6 & $\mathrm{Cu}(\mathrm{acac})_{2} / \mathrm{NH}_{2}-\mathrm{T} / \mathrm{SiO}_{2} @ \mathrm{Fe}_{3} \mathrm{O}_{4} \mathrm{NPs}(1.2)$ & 98 & 115 & 29 \\
7 & $\mathrm{Cu}(\mathrm{acac})_{2}(0.85)$ & 96 & 112 & 28 \\
\hline
\end{tabular}

${ }^{a}$ Reaction conditions: aldehyde ( $1 \mathrm{mmol}$ ), amine ( $\left.1 \mathrm{mmol}\right), \mathrm{Cu}(\mathrm{acac})_{2} / \mathrm{NH}_{2}-\mathrm{T} / \mathrm{SiO}_{2} @ \mathrm{Fe}_{3} \mathrm{O}_{4} \mathrm{NPs}$ $(0.85 \mathrm{~mol} \%)$, methanol $(5 \mathrm{ml}), \mathrm{RT}, 1 \mathrm{~h}$, then acetic acid $(1 \mathrm{mmol}), 15 \mathrm{~min}$, then cyclohexyl isocyanide $(1 \mathrm{mmol}), 4 \mathrm{~h}$

${ }^{\mathrm{b}} \mathrm{TON}$ (turnover number): mols of product obtained per mol of the catalyst

${ }^{\mathrm{c}} \mathrm{TOF}$ (turnover frequency) for $4 \mathrm{~h}$ of reaction

of $\mathrm{SiO}_{2} @ \mathrm{Fe}_{3} \mathrm{O}_{4} \mathrm{NPs}, \mathrm{NH}_{2}-\mathrm{T} / \mathrm{SiO}_{2} @ \mathrm{Fe}_{3} \mathrm{O}_{4} \mathrm{NPs}$ and $\mathrm{Cu}(\mathrm{acac})_{2} / \mathrm{NH}_{2}-\mathrm{T} / \mathrm{SiO}_{2} @ \mathrm{Fe}_{3} \mathrm{O}_{4} \mathrm{NPs}$ show Fe-O vibrations in the same vicinity. It was reported that $\mathrm{Fe}_{3} \mathrm{O}_{4}$ nanoparticles can take up extensive hydroxyl groups on their surface upon contact with aqueous phase through adsorption of $\mathrm{OH}^{-}$on $\mathrm{Fe}$ and $\mathrm{H}^{+}$on $\mathrm{O} .{ }^{52}$ This is confirmed by the broad $\mathrm{O}-\mathrm{H}$ stretching band at $3399 \mathrm{~cm}^{-1}$. The Si-O-Si asymmetric stretching vibration at $1082 \mathrm{~cm}^{-1}$ and symmetric stretching vibration at $796 \mathrm{~cm}^{-1}$ appear in all the samples, but $\mathrm{Fe}_{3} \mathrm{O}_{4} \mathrm{NPs}$, which indicates that silica is successfully coated on the surface of $\mathrm{Fe}_{3} \mathrm{O}_{4}$ nanocrystals upon hydrolysis of TEOS. Introduction of APTES to the surface of $\mathrm{Fe}_{3} \mathrm{O}_{4} \mathrm{NPs}$ is confirmed by the band at $1082 \mathrm{~cm}^{-1}$, which is assigned to the $\mathrm{Si}-\mathrm{O}$ stretching vibration. The broad band at $3404 \mathrm{~cm}^{-1}$ corresponds to $\mathrm{N}-\mathrm{H}$ stretching vibration. ${ }^{53}$ Presence of anchored propyl group

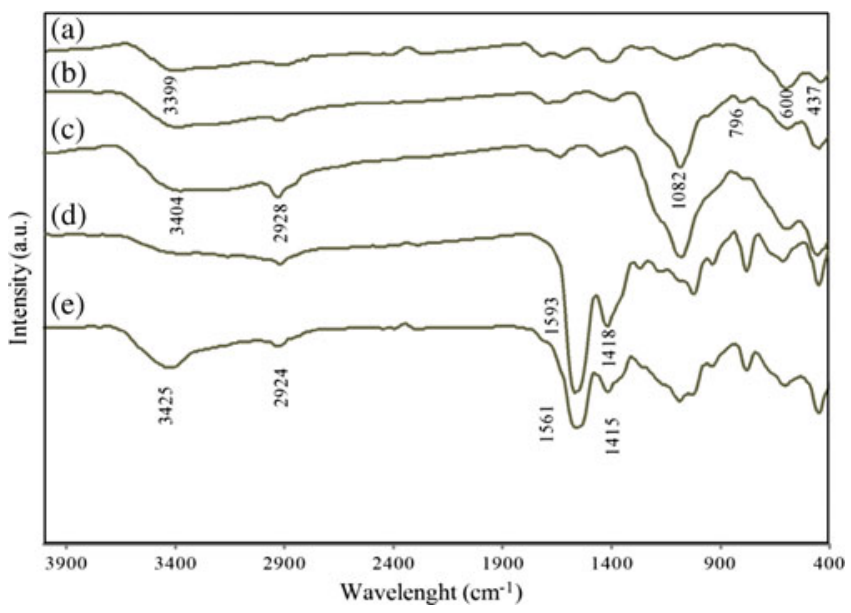

Figure 5. Comparative FTIR spectra for (a) $\mathrm{Fe}_{3} \mathrm{O}_{4} \mathrm{NPs}$, (b) $\mathrm{SiO}_{2} @ \mathrm{Fe}_{3} \mathrm{O}_{4} \mathrm{NPs}$, (c) $\mathrm{NH}_{2}-\mathrm{T} / \mathrm{SiO}_{2} @ \mathrm{Fe}_{3} \mathrm{O}_{4} \mathrm{NPs}$, (d) $\mathrm{Cu}(\mathrm{acac})_{2} / \mathrm{NH}_{2}-\mathrm{T} / \mathrm{SiO}_{2} @ \mathrm{Fe}_{3} \mathrm{O}_{4} \mathrm{NPs}$ and (e) recovered catalyst after usage. is confirmed by $\mathrm{C}-\mathrm{H}$ stretchings at $2928 \mathrm{~cm}^{-1}$. Spectrum of $\mathrm{Cu}(\mathrm{acac})_{2} / \mathrm{NH}_{2}-\mathrm{T} / \mathrm{SiO}_{2} @ \mathrm{Fe}_{3} \mathrm{O}_{4} \mathrm{NPs}$ exhibits well-defined bands at about 1593 and $1418 \mathrm{~cm}^{-1}$ due to $v(\mathrm{C}=\mathrm{O}$ and/or $\mathrm{C}=\mathrm{N})$ and $v(\mathrm{C}=\mathrm{C})$, respectively (figure 1d). This is a strong evidence for anchoring of $\left[\mathrm{Cu}(\mathrm{acac})_{2}\right]$ on the surface of $\mathrm{NH}_{2}-\mathrm{T} / \mathrm{SiO}_{2} @ \mathrm{Fe}_{3} \mathrm{O}_{4} \mathrm{NPs}$ through the Schiff condensation of $-\mathrm{NH}_{2}$ and $-\mathrm{CO}$ groups.

\subsection{Structural analysis of the catalyst and its components (via TGA)}

Thermogravimetric analysis curves of the $\mathrm{SiO}_{2} @$ $\mathrm{Fe}_{3} \mathrm{O}_{4} \mathrm{NPs}, \mathrm{NH}_{2}-\mathrm{T} / \mathrm{SiO}_{2} @ \mathrm{Fe}_{3} \mathrm{O}_{4} \mathrm{NPs}$ and $\mathrm{Cu}(\mathrm{acac})_{2} /$ $\mathrm{NH}_{2}-\mathrm{T} / \mathrm{SiO}_{2} @ \mathrm{Fe}_{3} \mathrm{O}_{4} \mathrm{NPs}$ show the mass loss of organic materials as they decompose upon heating (figure 6). Initial weight loss from the $\mathrm{SiO}_{2} @ \mathrm{Fe}_{3} \mathrm{O}_{4} \mathrm{NPs}$ up to $126^{\circ} \mathrm{C}$ is due to the removal of physically adsorbed

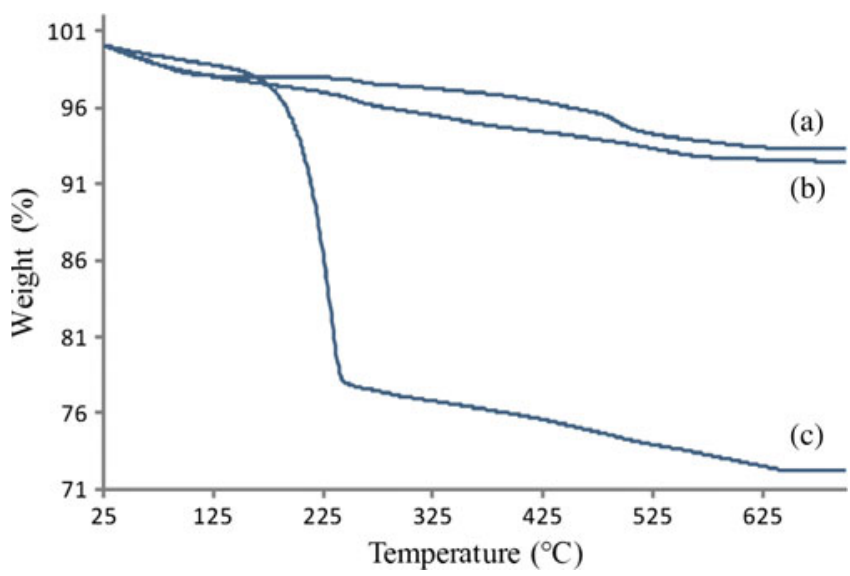

Figure 6. TGA curve of (a) $\mathrm{SiO}_{2} @ \mathrm{Fe}_{3} \mathrm{O}_{4} \mathrm{NPs}$, (b) $\mathrm{NH}_{2}-$ $\mathrm{T} / \mathrm{SiO}_{2} @ \mathrm{Fe}_{3} \mathrm{O}_{4} \mathrm{NPs}$ and (c) $\mathrm{Cu}(\mathrm{acac})_{2} / \mathrm{NH}_{2}-\mathrm{T} / \mathrm{SiO}_{2} @$ $\mathrm{Fe}_{3} \mathrm{O}_{4} \mathrm{NPs}$. 


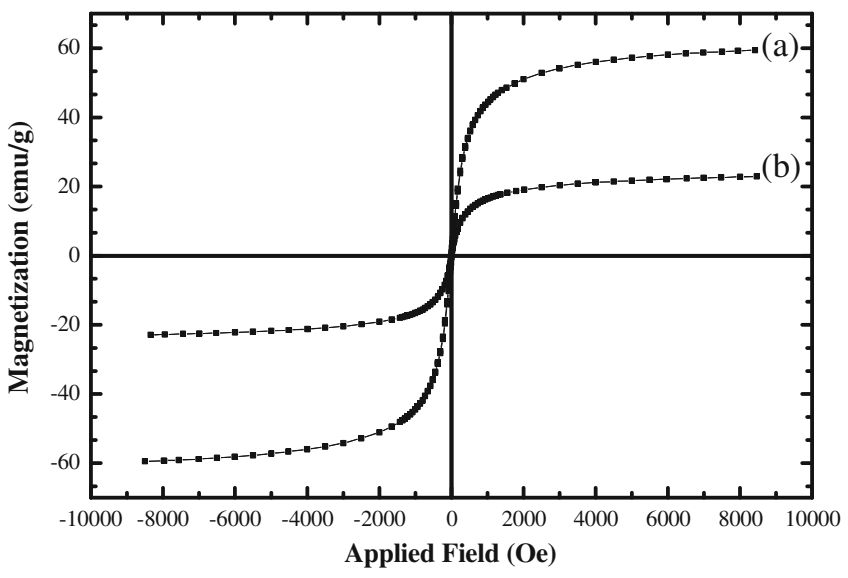

Figure 7. Magnetization curves for (a) $\mathrm{Fe}_{3} \mathrm{O}_{4} \mathrm{NPs}$ and (b) $\mathrm{Cu}(\mathrm{acac})_{2} / \mathrm{NH}_{2}-\mathrm{T} / \mathrm{SiO}_{2} @ \mathrm{Fe}_{3} \mathrm{O}_{4} \mathrm{NPs}$ at room temperature.

solvent and surface hydroxyl groups. Weight loss of about $1.67 \%$ between $192^{\circ}$ and $310^{\circ} \mathrm{C}$ may be associated with the thermal crystal phase transformation from $\mathrm{Fe}_{3} \mathrm{O}_{4}$ to $\gamma-\mathrm{Fe}_{2} \mathrm{O}_{3}$ (figure $6 \mathrm{a}$ and $\mathrm{b}$ ). ${ }^{49}$ High rate of weight loss in the temperature ranging from 250 $600^{\circ} \mathrm{C}$ for $\mathrm{SiO}_{2} @ \mathrm{Fe}_{3} \mathrm{O}_{4} \mathrm{NPs}$ may be attributed to the condensation of silanol groups in $\mathrm{SiO}_{2} @ \mathrm{Fe}_{3} \mathrm{O}_{4} \mathrm{NPs} .{ }^{55}$ Weight loss of APTES-modified $\mathrm{Fe}_{3} \mathrm{O}_{4} \mathrm{NPs}$ is about $3.06 \%$ at $379-568^{\circ} \mathrm{C}$, which is contributed to the thermal decomposition of the 3-aminopropyl groups (figure 6b). For $\mathrm{Cu}(\mathrm{acac})_{2} / \mathrm{NH}_{2}-\mathrm{T} / \mathrm{SiO}_{2} @ \mathrm{Fe}_{3} \mathrm{O}_{4} \mathrm{NPs}$, there is a well-defined mass weight loss of $21.3 \%$ between $135^{\circ}$ and $282^{\circ} \mathrm{C}$ related to the breakdown of the $\mathrm{Cu}(\mathrm{acac})_{2}$ moieties. On the basis of these results, the well grafting of APTES and $\mathrm{Cu}(\mathrm{acac})_{2}$ groups on the $\mathrm{Fe}_{3} \mathrm{O}_{4} \mathrm{NPs}$ is verified.

\subsection{Magnetic properties of $\mathrm{Fe}_{3} \mathrm{O}_{4} \mathrm{NPs}$ and $\mathrm{Cu}(\text { acac })_{2} /$ $\mathrm{NH}_{2}-\mathrm{T} / \mathrm{SiO}_{2} @ \mathrm{Fe}_{3} \mathrm{O}_{4} \mathrm{NPs}$ (via VSM)}

Super-paramagnetic behaviour is attributed to both $\mathrm{Fe}_{3} \mathrm{O}_{4} \mathrm{NPs}$ precursor and $\mathrm{Cu}(\mathrm{acac})_{2} / \mathrm{NH}_{2}-\mathrm{T} / \mathrm{SiO}_{2} @$ $\mathrm{Fe}_{3} \mathrm{O}_{4} \mathrm{NPs}$ for exhibiting VSM magnetization values of 60.0 and $23.0 \mathrm{emu} / \mathrm{g}$, respectively ${ }^{56}$ (figure 7). Evidently, lower magnetization of the latter is due to the extensive silica coatings of the magnetic core and its functionalizations. Yet, decrease in magnetization does not prevent $\mathrm{Cu}(\mathrm{acac})_{2} / \mathrm{NH}_{2}-\mathrm{T} / \mathrm{SiO}_{2} @ \mathrm{Fe}_{3} \mathrm{O}_{4} \mathrm{NPs}$ from being readily separated by conventional magnets.

\subsection{Evaluation of catalyst activity through $U-4 C R$}

In order to evaluate the catalytic activity of our $\mathrm{Cu}(\mathrm{acac})_{2} / \mathrm{NH}_{2}-\mathrm{T} / \mathrm{SiO}_{2} @ \mathrm{Fe}_{3} \mathrm{O}_{4} \mathrm{NPs}$, it is applied to $\mathrm{U}-4 \mathrm{CR}^{25}$ for generating $\alpha$-aminoacyl amide derivatives by condensing an aldehyde, amine, carboxylic acid and isocyanide.

Table 3. Ugi one-pot catalytic synthesis of $\alpha$-aminoacyl amides (I, scheme 2) via $\mathrm{Cu}(\mathrm{acac})_{2} / \mathrm{NH}_{2}-\mathrm{T} / \mathrm{SiO}_{2} @ \mathrm{Fe}_{3} \mathrm{O}_{4} \mathrm{NPs}^{\mathrm{a}}$

\begin{tabular}{|c|c|c|c|c|c|}
\hline Entry & $R^{1}$ & $R^{2}$ & Time (h) & Catalyst & Yield (\% I) \\
\hline 1 & Phenyl & $n$-Butyl & 4 & $\sqrt{ }$ & 89 \\
\hline 2 & 2-Methylphenyl & $n$-Butyl & 4 & $\sqrt{ }$ & 95 \\
\hline 3 & 4-Methylphenyl & $n$-Butyl & 4 & $\sqrt{ }$ & 94 \\
\hline 4 & 2-Chlorophenyl & $n$-Butyl & 4 & $\sqrt{ }$ & 87 \\
\hline 5 & 4-Bromophenyl & $n$-Butyl & 4 & $\sqrt{ }$ & 92 \\
\hline 6 & 4-Hydroxyphenyl & $n$-Butyl & 4 & $\sqrt{ }$ & 85 \\
\hline 7 & 4-Trifluoromethylphenyl & n-Butyl & 4 & $\sqrt{ }$ & 93 \\
\hline 8 & Phenyl & Phenyl & 4 & $\sqrt{ }$ & 98 \\
\hline 9 & 2-Methylphenyl & Phenyl & 4 & $\sqrt{ }$ & 96 \\
\hline 10 & Ethyl & Phenyl & 4 & $\sqrt{ }$ & 76 \\
\hline 11 & Pyridine-2-yl & $n$-Butyl & 24 & $\sqrt{ }$ & - \\
\hline 12 & Pyridine-3-yl & $n$-Butyl & 24 & $\sqrt{ }$ & - \\
\hline 13 & Pyridine-4-yl & $n$-Butyl & 24 & $\sqrt{ }$ & - \\
\hline 14 & Pyrrole-2-yl & $n$-Butyl & 24 & $\sqrt{ }$ & - \\
\hline 15 & Phenyl & $n$-Butyl & 24 & - & 54 \\
\hline 16 & Phenyl & Phenyl & 24 & - & 68 \\
\hline 17 & 2-Methylphenyl & Phenyl & 24 & - & 75 \\
\hline
\end{tabular}

a Reaction conditions: aldehyde ( $1 \mathrm{mmol})$, amine ( $1 \mathrm{mmol}), \mathrm{Cu}(\mathrm{acac})_{2} / \mathrm{NH}_{2}-\mathrm{T} / \mathrm{SiO}_{2} @ \mathrm{Fe}_{3} \mathrm{O}_{4} \mathrm{NPs}$ $(0.85 \mathrm{~mol} \%)$, methanol $(5 \mathrm{ml}), \mathrm{RT}, 1 \mathrm{~h}$, then acetic acid $(1 \mathrm{mmol}), 15 \mathrm{~min}$, then cyclohexyl isocyanide (1 mmol), $4 \mathrm{~h}$ 


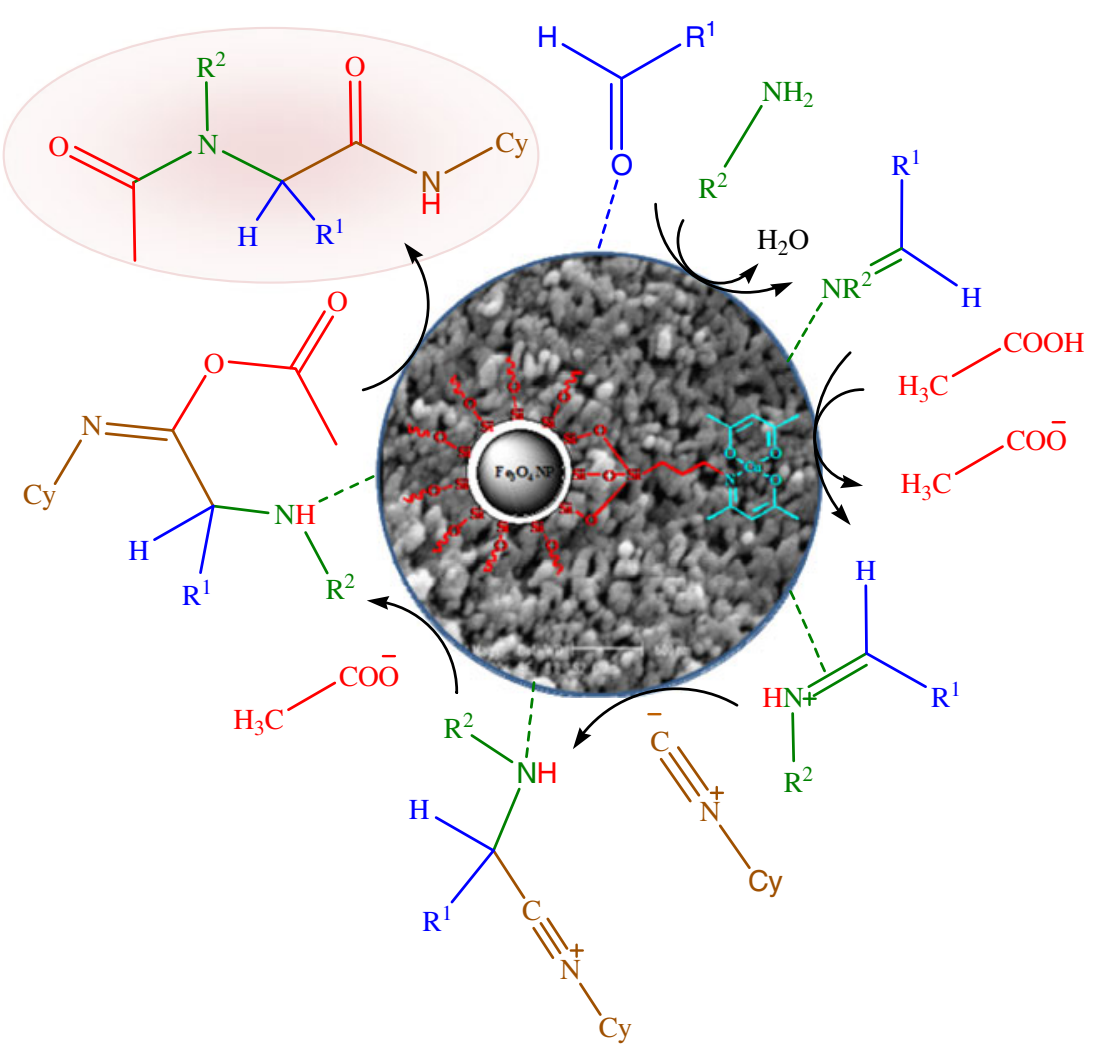

Scheme 3. A provisional mechanism for the role of $\mathrm{Cu}(\mathrm{acac})_{2} / \mathrm{NH}_{2}-\mathrm{T} / \mathrm{SiO}_{2} @ \mathrm{Fe}_{3} \mathrm{O}_{4} \mathrm{NPs}$ in U-4CR.

In order to optimize amount of catalyst, Ugi reaction is carried out using benzaldehyde, aniline, acetic acid and cyclohexyl isocyanide, in $\mathrm{MeOH}$ at room temperature. In the absence of the catalyst, about $10 \%$ of product is obtained after $4 \mathrm{~h}$ (table 2 , entry 1 ). The yield of product is increased with increase of the amount of nanocatalyst from 0.25 to $0.85 \mathrm{~mol} \%$ (table 2 , entries $2-4)$. However, greater amounts than $0.85 \mathrm{~mol} \%$ have no significant effect on the yield (table 2, entries 5 and 6). So, the optimum amount of catalyst is $0.85 \mathrm{~mol} \% / \mathrm{mmol}$ of benzaldehyde which resulted in $98 \%$ yield of the product after $4 \mathrm{~h}$.

The $\mathrm{Cu}(\mathrm{acac})_{2} / \mathrm{NH}_{2}-\mathrm{T} / \mathrm{SiO}_{2} @ \mathrm{Fe}_{3} \mathrm{O}_{4} \mathrm{NPs}$ acts as a heterogeneous catalyst in Ugi reaction, with TON and TOF similar to the ones obtained with homogeneous phase reaction performed with $\left[\mathrm{Cu}(\mathrm{acac})_{2}\right]$, under comparable experimental conditions (table 2, entries 4 and 7).

Products of various aromatic as well as aliphatic aldehydes and amines are isolated by filtration or column chromatography, in good to excellent yields (table 3). Purity and structural analysis of the products are mainly established by NMR, IR and mass spectroscopy (supporting information). Reaction time decreases to the unprecedented $4 \mathrm{~h}$, which is a noticeable improvement from the previously reported 24$72 \mathrm{~h} .{ }^{26}$ Another advantage of our new catalyst is its selectivity between aromatic and heteroaromatic aldehydes. While aromatic (and aliphatic) aldehydes render pure products in good to high yields, within $4 \mathrm{~h}$ (entry 1-10, table 3); heteroaromatic aldehydes do not produce any product, even with an extended reaction time of $24 \mathrm{~h}$ (entry 11-14, table 3 ). In the absence of catalyst,

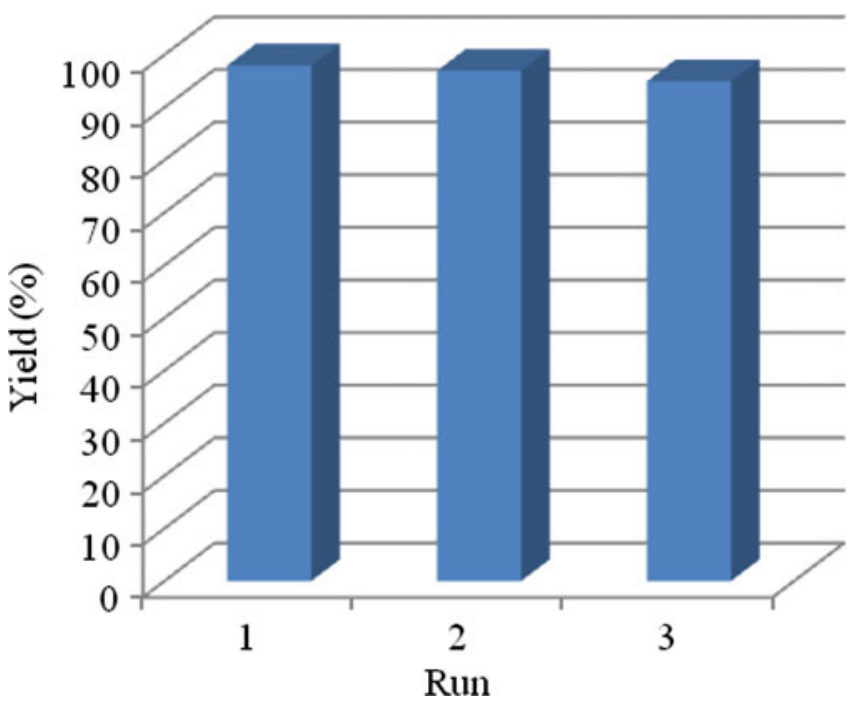

Figure 8. Efficiency of catalyst in Ugi reaction of benzaldehyde, aniline, acetic acid and cyclohexyl isocyanide (scheme 2) after each run. 
similar reactions result in low yields with long reaction times (entry $15-17$, table 3 ).

The role of our catalyst may be explained in light of its ability to provide a suitable surface for performing U-4CR (scheme 3). Sequentially, $\mathrm{Cu}(\mathrm{acac})_{2} / \mathrm{NH}_{2}-$ $\mathrm{T} / \mathrm{SiO}_{2} @ \mathrm{Fe}_{3} \mathrm{O}_{4} \mathrm{NPs}$ facilitates the formation of imine, by increasing the electrophilicity of the carbonyl group of the aldehyde. The reaction proceeds via activation of resulting imine, by the nanocatalyst and its further reaction with acetic acid and cyclohexyl isocyanide to form an intermediate, which in turn rearranges to the $\alpha$-aminoacyl amide. On the other hand, heteroaromatic aldehydes seem to poison the catalyst giving no product at all. This adds to the value of the nanocatalyst for making it highly selective.

Preservation of structural integrity of the catalyst is suggested by the minimal changes in its efficiency after three runs (figure 8) and confirmed by the comparison of its FTIR spectra before and after its implementation (figure $5 \mathrm{~d} v s$. e).

\section{Conclusion}

We have successfully prepared a new magnetically recoverable nanocatalyst $\left(\mathrm{Cu}(\mathrm{acac})_{2} / \mathrm{NH}_{2}-\mathrm{T} / \mathrm{SiO}_{2} @\right.$ $\mathrm{Fe}_{3} \mathrm{O}_{4} \mathrm{NPs}$ ), which is applied to one-pot synthesis of $\alpha$ aminoacyl amides, through Ugi four-component reaction (U-4CRs). This investigation clearly shows that our catalytic system drastically decreases reaction time, increases yield, and more importantly exhibits a high selectivity for aromatic aldehydes, to the extent that it forms no product from the heteroaromatic ones.

\section{Supporting information}

Data of NMR and IR spectra are given as supporting information and can be seen at www.ias.ac.in/chemsci website.

\section{References}

1. Beller M and Bolm C 2004 In Transition metals for organic synthesis, 2nd ed. (Weinheim: Wiley-VCH)

2. Lam P Y S, Vincent G, Bonne D and Clark C G 2003 Tetrahedron Lett. 444927

3. Beveridge R E, Fernando D and Gerstenberger B S 2010 Tetrahedron Lett. 515005

4. Garrett C E and Prasad K 2004 Adv. Synth. Catal. 346 889

5. Silva A R, Wilson K, Whitwood A, Clark J and Freire C 2006 Eur. J. Inorg. Chem. 1275

6. Panda N, Jena A K and Mohapatra S 2012 Appl. Catal. A: Gen. $\mathbf{4 3 3}-\mathbf{4 3 4} 258$

7. Karthikeyan P, Muskawar P N, Aswar S A, Bhagat P R and Sythana S K 2012 J. Mol. Catal. A: Chem. 358112
8. Fan Q-H, Li Y-M and Chan A S C 2002 Chem. Rev. 102 3385

9. Esmaeilpour M, Sardarian A R and Javidi J 2012 Appl. Catal. A: Gen. 28359

10. Leadbeater N E and Marco M 2002 Chem. Rev. 1023217

11. Rafelt J S and Clark J H 2000 Catal. Today 5733

12. Arends I W C E and Sheldon R A 2001 Appl. Catal. A: Gen. 212175

13. Kantam M L, Kavita B, Neeraja V, Haritha Y, Chaudhuri M K and Dehury S K 2003 Tetrahedron Lett. 449029

14. Silva A R, Martins M, Freitas M M A, Figueiredo J L, Freire C and de Castro B 2004 Eur. J. Inorg. Chem. 2027

15. Silva A R, Figueiredo J L, Freire C and de Castro B 2005 Catal. Today 102154

16. Cano R, Yus M and Ramón D J 2011 Tetrahedron 67 8079

17. Khoobia M, Ma'mania L, Rezazadehb F, Zareieb Z, Foroumadia A, Ramazanib A and Shafiee A 2012 J. Mol. Catal. A: Chem. 35674

18. Kong A, Wang P, Zhang H, Yanga F, Huang S and Shan Y 2012 Appl. Catal. A: Gen. 417-418 183

19. Claesson E M, Mehendale N C, Gebbink R J M K, Koten G V and Philipse A P 2007 J. Magn. Magn. Mater. 31141

20. Masteri-Farahani M and Kashef Z 2012 J. Magn. Magn. Mater. 3241431

21. Bagheri M, Masteri-Farahani M and Ghorbani M 2013 J. Magn. Magn. Mater. 32758

22. Masteri-Farahani M and Tayyebi N 2011 J. Mol. Catal. A: Chem. 34883

23. Masteri-Farahani M, Movassagh J, Taghavi F, Eghbali P and Salimi F 2012 Chem. Eng. J. 184342

24. Deng Y, Qi D, Deng C, Zhang X and Zhao D 2008 J. Am. Chem. Soc. 13028

25. Dömling A and Ugi I 2000 Angew. Chem. Int. Ed. 39 3169

26. Krasavin M, Parchinsky V, Shumsky A, Konstantinov I and Vantskul A 2010 Tetrahedron Lett. 511367

27. Dömling A 2006 Chem. Rev. 10617

28. Kunz H and Pfrengle W 1988 J. Am. Chem. Soc. 110 651

29. Kunz H and Pfrengle W 1988 Tetrahedron 445487

30. Kunz H, Pfrengle W and Sager W 1989 Tetrahedron Lett. 304109

31. Kunz H, Pfrengle W, Rück K and Sager W 1991 Synthesis 111039

32. Goebel M and Ugi I 1991 Synthesis 1095

33. Lehnhoff S, Goebel M, Karl R M, Klösel R and Ugi I 1995 Angew. Chem. Int. Ed. 341104

34. Oertel K, Zech G and Kunz H 2000 Angew. Chem. Int. Ed. 391431

35. Ross G F, Herdtweck E and Ugi I 2002 Tetrahedron 58 6127

36. Godet T, Bonvin Y, Vincent G, Merle D, Thozet A and Ciufolini M A 2004 Org. Lett. 63281

37. Dai W-M and Li H 2007 Tetrahedron 6312866

38. Cullity B D and Stock S R 2001 In Elements of X-ray diffraction, 3rd ed. (Englewood Cliffs: Prentice-Hall)

39. Jiang Y, Jiang J, Gao Q, Ruan M, Yu H and Qi L 2008 Nanotechnology 1975714

40. Nasibulin A G, Kauppinen E I, Brown D P and Jokiniemi J K 2001 J. Phys. Chem. B105 11067 
41. Liu B and Zeng H C 2008 Chem. Mater. 202711

42. Chen X and Burda C 2004 J. Phys. Chem. B108 15446

43. Iwanowskia R J, Fronca K, Paszkowicza W and Heinonenb M 1999 J. Alloys Compd. 286143

44. Bhattacharyya S, Hong J and Turban G 1998 J. Appl. Phys. 833917

45. Marton D, Boyd K J, Al-Bayati A H, Todorov S S and Rabalais J W 1994 Phys. Rev. Lett. 73118

46. Tabbal M, Mérel P, Moisa S, Chaker M, Ricard A and Moisan M 1996 Appl. Phys. Lett. 691698

47. Valente A, Botelho do Rego A M, Reis M J, Silva I F, Ramos A M and Vital J 2001 Appl. Catal. A: Gen. 207 221

48. de Groot F 2005 Coord. Chem. Rev. 24931
49. Casttilla C M, Cadenas A P, Hódar F M, Marín F C and Fierro J L 2003 Carbon 411157

50. Rao Z M, Wu T H and Peng S Y 1995 Acta Phys. Chim. Sin. 11395

51. Waldron R D 1955 Phys. Rev. 991727

52. Shinkai M, Honda H and Kobayashi T 1991 Biocatalysis 561

53. Xu Z, Liu Q and Finch J A 1997 Appl. Surf. Sci. 120269

54. Cornell R M and Schwertmann U 1996 The iron oxides (New York: VCH)

55. Feng G, Hu D, Yang L, Cui Y, Cui X and Li H 2010 Sep. Purif. Technol. 74253

56. Laska U, Frost C G, Price G J and Plucinski P K 2009 J. Catal. 268318 